\title{
The behavioral turn in development economics: a tentative account through the lens of economic methodology
}

\author{
A guinada comportamental na economia do desenvolvimento: \\ uma análise preliminar pelas lentes da metodologia econômica
}

ROBERTA MURAMATSU

FLAVIA AVILA*

\begin{abstract}
RESUMO: Este artigo busca oferecer uma interpretação sobre por que insights da economia comportamental foram incorporados à agenda de pesquisa sobre o desenvolvimento econômico inspirada pelas lentes da metodologia da economia. Embarca-se em uma revisão extensa da literatura que se concentra na prática efetiva "da análise comportamental do desenvolvimento econômico e visão da economia comportamental da pobreza”. Tal agenda surgiu nos primeiros anos do século XXI para identificar e discutir algumas direções e implicações que esse movimento pode trazer para a ciência e arte da Economia.

PALAVRAS- CHAVE: Economia comportamental; desenvolvimento; experimentos de campo; metodologia; política.
\end{abstract}

ABSTRACT: This paper aims to provide an interpretation of why behavioral economics has come into the complex field of development economics that draws on insights from methodology of economics. We engage in an extensive survey of the literature that focuses on the actual practice of "behavioral development economics and behavioral economics view of poverty" that emerged in the early years of the 21 st century in order to identify and discuss some directions and implications that this movement might carry for economics science and art of Economics.

KEYWORDS: Behavioral economics; development; field experiments; methodology; policy. JEL Classification: B40; B41; D11; D91.

\footnotetext{
* Adjunct Professor of Economics, Universidade Presbiteriana Mackenzie, Email robertamuramatsu@ gmail.com, robertam@insper.edu.br, roberta.muramatsu@mackenzie.br; Posgraduate Program Coordinator and Lecturer of Behavioural Economics, ESPM - Escola Superior de Propaganda e Marketing, e-mail: flavia.avila@espm.br. Submetido: 17/August/2015; Approved: 11/April/2016.
} 


\section{INTRODUCTION}

Behavioral Economics and its empirical applications have gained its momentum at the end of the $20^{\text {th }}$ century (Angner and Loewenstein, 2012; Heukelom, 2013). It goes on to hold the promise of changing the face of neoclassical financial economics, labor economics, health economics, environmental economics, law and economics, among others (Camerer, Loewenstein and Rabin, 2004; Diamond and Vartiainen, 2007; DellaVigna, 2009). Not only does the behavioral move in economic analysis purport to provide psychologically more plausible accounts of actual behavior, it aims to guide regulation and policy that help boundedly rational people to choose in their best interests (Camerer et al., 2003, Thaler and Sunstein, 2003, Thaler and Sunstein, 2009; Sunstein, 2012). Very recently, behavioral economics has inspired the theory as well as the practice of development economics (Bertrand, Mullanaithan and Shafir, 2004; Mullanaithan, 2007; Hands 2012). There is already a vast literature shedding light on the prospects of using insights from behavioral economics in the fight against poverty (Banerjee and Duflo, 2012; Karlan and Appel, 2012; Mullanaithan and Shafir, 2013). In a similar trend, the March 2014 edition of the Review of Income and Wealth consists of a special edition with eight papers that somehow anticipate the higher explanatory consequences of broadening the economic approach to human behavior for the accounts of poverty and development (Jäntti, Kanbur and Pirttila, 2014).

Our point of departure in this paper is the view that methodology of economics help understand why and perhaps how researchers on development and poverty accommodate the behavioral approach and what implications all this might carry (Hands, 2012).

More precisely, it aims to provide an interpretation of why behavioral economics has come into the complex field of development economics informed by economic methodology. We embark on an extensive survey of the literature that focuses on the actual practice of "behavioral development economics and behavioral economics view of poverty" that emerged in the early years of the $21^{\text {st }}$ century in order to identify and discuss some directions and implications that this movement might carry for economics science and policy.

In order to pursue the foregoing task, it conjectures that there are at least two factors explaining the exchange of knowledge between behavioral economics and development economics. One is the acknowledgment that ineffectiveness of development programs or policies might have to do with the fragile psychological foundations of mainstream economic theory (Duflo and Banerjee, 2012). Another is the recognition that field experiments with randomized controlled trial or randomized evaluation (pioneered by researchers of MIT's Abdul Latif Jameel Poverty Action Lab in 2003) are useful methodological tools for the advancement of evidencebased policy design.

The remainder of this paper is structured as follows. The first section attempts to present and analyze the so-called behavioral economics view of poverty and development (Bertrand et al., 2004). Furthermore, it discusses some institutional 
and cognitive constraints that often prevent the destituted to achieve what it is in their best interests. Second section provides an interpretation of why the behavioral approach has gained enormous popularity and how this relates to an effort to fill some explanatory, predictive and prescriptive blanks that neoclassical economics has left. Third section provides some further evidence about the great explanatory prospects of behavioral economic applications to development. Fourth section discusses the implications of the behavioral turn for economic development. It weighs out the arguments for and against behaviorally informed interventions. The last section wraps the overall argument up and concludes.

\section{BEHAVIORAL ECONOMICS VIEWS OF POVERTY AND DEVELOPMENT}

It is a commonplace to state that poverty cannot be reducible to material or income deprivation. Instead, it is a complex and multifaceted phenomenon involving cognitive, motivational, sociological, historical and institutional dimensions in need of ongoing inquiry (Prebisch, 1949; Furtado, 1974; Sen, 2000; Narayan et al., 2000).

\section{In search of a behavioral approach to help better development and policy design}

Inspired by the literature on human development, we take poverty as deprivation from basic capabilities, which is a denial of opportunities and choices for individuals to be nourished; to avoid premature death; to have access to good schools or public services; to establish a standard of living that they value highly; to be socially and financially included and so forth. As a result, we focus on a view of development as a complex network of processes of various dimensions and sectors to enhance people's capabilities, well-being and quality of life. With this in mind, development policies or programs are to enable people to live the lives they value and to help them pursue and achieve their potential. Yet their effectiveness are also dependent on whether institutions and organizations can really allow people to be the main actors of their own destiny and therefore to advance human agency and flourishing (Alkire and Deneulin, 2009).

The growing field of behavioral economics has collected robust evidence that human agency might not be only constrained by laws, contracts and institutions but by individuals' perception of decision tasks, default rules, self control problems, power of inertia and particular microincentives (Duflo, 2012; Datta and Mullanaithan, 2014). The conviction that poor people face various external and internal constraints on judgment and decision-making that, under particular and predictable contexts, prevent them from choosing in their best interests is certainly at the core of the "Behavioral Economics View of Poverty" (Bertrand et al., 2004). This is far from being a very accurate explanation of poverty. In such perspective, development depends on initiatives like policies, programs, regulatory schemes that 
enable individuals to advance their potential of human agency by approximating their revealed intentions and actions.

There are two standard types of theorizing about poverty, to which behavioral economics oppose. One takes poverty as a result from choices that reveal adapted preferences to prevailing circumstances, to which low-income individuals are subject. It assumes that people are fully rational and their behaviors result from calculated adaptations. Another type draws from the Victorian mentality that there is a culture of poverty. The second approach suggests that poor people exhibit impulsive and suboptimal patterns of behavior because their preferences and beliefs are misguided and irrational.

Quite recently, behavioral development researchers Sendhil Mullanaithan and Eldar Shafir propose a third view of poverty. According to their perspective, poverty results from features of the institutional environment that make decisionmaking of the poor a complex task and therefore constrain individuals to make critical judgments and choices conducive to a path of capability expansion with improved quality of life.

Mullanaithan and Shafir (2013) make the bold claim that the main problem is how to help the poor to resolve their "packing problem". Poor people have too many things (complex tasks) to pack in a too small suitcase. The underlying idea is that even if people living in the condition of poverty could make all the right (or optimal) choices for satisfying their basic needs, this would come with a high cost and necessarily constrain important decisions in other domains of their lives (Duflo, 2012). Furthermore, the constant challenge of managing everyday minor emergencies affect very severely poor people's time preferences. Under the hostile conditions of scarcity that characterize poverty, individuals are not free to pursue and achieve what they want to be and do. As a result, many of them lose part of their ability to plan, to stick to their future goals. Because of such complexity, they often opt for an immediate lower reward to the detriment of higher future gains.

\section{Factors that might constrain decision-making among the poor severely}

Various lab as well as field experiments (to be presented and discussed above) suggest that poverty also persists because of some situational factors and cognitive limitations that undermine individual capacity of behaving in certain ways conducive to the pursuit of their long-term interests and goals. We focus on: (a) high transaction costs, including low government credibility; (b) the important role of contexts and default rules and (c) self-control problems and the demand for commitment

\section{High transaction costs and little credibility or reputation}

Development economists are very aware of the serious problem of low uptake rates of important development policies or programs related to child vaccination, 
microsavings initiaves and water quality or treatment. High transaction costs often represent a non-negligible obstacle.

Some vaccination campaigns fail to achieve their targets because of the geographical distance of free immunization centers. Banerjee et al., (2010) tried to come to grips with this problem in India with a field experiment that offered a half-kilo bag of lentils to parents who actually brought their children to get a vaccine. The number of immunized kids almost doubled.

Transaction costs can also be a major barrier for the poor to have real access to formal financial services and eventually effective savings products. Examples of factors that explain why the poor are "unbanked" abound - bank account fees, minimum balance requirements, transportation costs, etc (Dupas and Robinson, 2013). Bank credibility and reputation also prevent low-income people to be financially included and motivate them to opt for informal (risky) financial services and products (Dupas et al., 2012).

\section{Context dependencies, framing effects and the relevance of default rules}

One of the biggest claims behavioral economists make based on Daniel Kahneman and Amos Tversky's research is that our judgment and decision-making are sensitive to contexts and perceptions of relative losses or gains dubbed as frames (Kahneman and Tversky 1979, Kahneman 2003).

In order to economize on cognitive resources, boundedly rational agents draw on automatic choice procedures called default rules. Under very predictable contexts, people prefer not to choose and follow cue-based mental shortcuts or heuristics. There is a vast literature suggesting that economically relevant choices ranging from organ donation, food consumption to savings reveal the role of default rules in the explanation of actual behavior (Beshears et al., 2012).

One economic domain that default roles play major roles is in retirement plans or savings. Even when there are material incentives to save for tomorrow (i.e. employers also contribute to employers retirement accounts up to a certain amount), many workers either stick to the lowest savings rate or even do not adhere to pension programs. Madrian and Shea (2001) investigated empirically the importance of the default rule in the $401(\mathrm{k})$ plan and its impact on savings behavior. They observed that when adhering to the $401(\mathrm{k})$ plan was not a default, only $38 \%$ of the workers contributed to such contribution defined retirement account. However, when the default became automatic enrollment, contributions increased by $86 \%$.

Default rules also play major roles in low-income workers'consumption and savings behavior (Banerjee and Duflo, 2012). Although several studies have been suggesting the role of default rules in explaining low-income people's savings behavior, other factors that deserve attention (e.g. low literacy and complexity of financial products and services). 


\section{Overcoming self-control and credible commitment problems}

The human tendency to prefer an immediate gratification over a higher future outcome is a pervasive phenomenon. Self-control problems and difficulty with resisting to temptation amplify the complexity of intertemporal decision-making in the real world (Frederick et al., 2002; Banerjee and Mullainathan 2010).

There is a growing body of evidence about the impact of time inconsistency and temptation on decision-making by the poor (Ashraf et al., 2006; Banerjee and Mullainathan, 2009; Karlan et al., 2014). Experimental findings show that cognitive biases shape decision-making among the poor and the rich in predictable ways, though the welfare consequences of choice mistakes are worse for low-income individuals. Banerjee and Duflo (2007) notes that the poor are more subject to temptation and tend to choose immediate gratification. They emphasize that this is not due to greater irrationality among the poor. Poor people cannot save much or even alone because of their low income and various other situational factors (non-availability or ineffectiveness of microfinance institutions, uncertain work environment, etc) that reward present-biased preferences highly.

Behavioral economists often account for intertemporally inconsistent behaviors in terms of a (quasi) hyperbolic discount function. The latter is a mathematically tractabe way of representing present bias and the tendency towards procrastination. Empirical development studies that incorporate hyperbolic discounting have suggested alternative interpretations of why low-income households have a difficult time keeping their children at school and why small farmers cannot translate their intention of fertilizer use into actions.

\section{MAKING SENSE OF BEHAVIORAL ECONOMIC APPLICATIONS TO DEVELOPMENT}

In his essay "The Methodology of Positive Economics", Milton Friedman argued that economis is an objective science and meaningful prediction is the ultimate goal of any positive economic theory/model (1953, pp. 4-7).

It is important to stress that Friedman's emphasis on predictive accuracy of a theory offers a criterion by which contemporary economists often evaluate the goodness of any economic model/theory. Another important methodological contribution he made concerns the debate over unrealistic assumptions. To him, 'the better the economic theory, the more unrealistic its assumptions' (ibid., p. 11). Friedman was partly successful in convincing economists that the issue of realism of an assumption was not the big issue because all theories and models necessarily involve simplifying assumptions, that is, descriptively unrealistic statements with different roles in theorizing (Hands, 2011). ${ }^{1}$

\footnotetext{
${ }^{1}$ For a careful debate over this methodological hot topic, see Mäki (1989, 1992, 1994, 2009).
} 


\section{Early methodological differences between Friedman and behavioral economists}

In the early 1990s, behavioral economists presented themselves as critics of Friedman's methodology. They appealed to Herbert Simon's ideas to suggest that the goodness of a model or theory depends on whether its underlying psychological assumptions are acceptably unrealistic. Colin Camerer and George Loewenstein defined behavioral economics in terms of the conviction that increasing the realism of economic assumptions will improve the quality of economic models and theories is at the core of behavioral economic analysis $(2004$, p. 3$)$.

Additionally, the view that certain unrealistic assumptions (e.g. consistent time preferences, coherent risk perception and preferences) constrain the predictive capabilities of neoclassical economics is an effective component of the rhetoric of behavioral economics. Just like Friedman, behavioral economists also regard meaning prediction as their goal. To them, it is worthwhile to add more explanatory factors to the standard model of choice if the reformed model can predict choice behavior already covered by conventional models as well as the so-called empirical deviations about anomalies (Kahneman, Tversky, Knetsch and Thaler, 1986).

Nevertheless, there seem to be quite significant differences in behavioral economists' methodological commitments. They do not share the view that prediction is the only goal of economic models/theories or that explanation is just like prediction of already known events. Explanation refers to redescription of empirically grounded items (i.e. cognitive, emotional, brain mechanisms and processes)) that are causally relevant to production of actual behavior patterns.

\section{Experiments to improve economic predictions and explanations}

In tune with the long-standing tradition regarding economics as a non-experimental science, Friedman (1953) emphasizes that one cannot test particular theories and their prediction by experiments because of our inability to accommodate all the disturbing factors and conduct a controlled experiments. In response to the difficulty with experiment control and replication, economists might benefit from "evidence cast up by experience" (Friedman, 1953, p. 10).

Yet Vernon Smith's experimental economics as well as Daniel Kahneman and Amos's Tversky behavioral experimental contributions have gained popularity over time and sensitized mainstream practitioners in need of broadening their empiritcal toolbox and gaining predictive and explanatory capacity.

With some concessions made, economics in the $21^{\text {st }}$ century turned out to be an experimental science (Smith, 1982, 1989; Bianchi and Silva, 2011; Battisti, 2012). Since the 1980s there has been an exponencial growth in publications that take experimental methods explicitly in their explanations and predictions of economic phenomena (Starmer 1999; Bardsley et al., 2010).

Until the end of the $20^{\text {th }}$ century most experiments were designed and run in the laboratory with hypothetical choices. In such settings, researchers ask partici- 
pants to answer questions that cannot be addressed by non-experimental data. The promise of a lab experiment is that it isolates variables from other explanatory items that are difficult to investigate in the real world. Another advantage is the controlled environment where few factors are manipulated while holding others constant or even excluded. This help researchers detect behavioral regularities, test economic theories and to examine policy recommendations. Moreover, carefully designed experiments try to overcome the selection bias problem by randomly allocating participants in treatment and control groups.

Despite the various accomplishments of lab experiments, their lack of realism and artificiality still trouble experimentalists. Objections to the experimental method always refer to two problems, the so-called external and internal validity problems.

External validity refers to the difficulty with drawing inferences about the real economic world from evidence from the idealized environment of a laboratory. Internal validity has to do with the robustness and replicabity of the experimental design and the challenge of distinguishing causal mechanisms and processes from statistical associations detected in the laboratory.

According to Angner and Loewenstein (2012), experiments with hypothetical choices were replaced with those with real outcomes in the 1990s. This trend evolved to field experiments that is now the "gold standard" for research in behavioral economics (p. 42).

\section{Field experiments in development economics}

One of the strengths of a field experiment is that it is run in a naturally occurring environment, with real stakes. It has the advantage of selecting subjects that are unaware of the fact that they are part of an experiment and therefore have the incentive to behave more spontaneously and perform decision tasks of their daily lives (Levitt and List, 2008).

Experimental research in the field can shed light on important research areas in development, such as education and microcredit. Field experiments have evolved both as a testing ground of traditional theories and as a useful development economist's toolbox for policy evaluation. There are different kinds of field experiments. One of them specifically plays central role in development economics: randomized controlled trials (RCTs).

Randomized controlled trials (RCTs) offer one of the most direct ways of obtaining evidence about individual choices. They are often used to evaluate simultaneously the relative effectiveness of different possible interventions (via regulation, policy or financial institutions themselves) by randomly allocating individuals to a "treatment group" (which will be exposed to a program) and to a "control group" (which will not). Then, results between the treatment and the control group can be compared (Duflo, Glennerster and Kremer, 2008).

Randomization is also a way to deal with the problem of selection bias, since individuals and groups are randomly assigned to treatment and control conditions. Field experiments also make it possible to vary one factor at a time. Furthermore, 
well-designed and implemented field experiments provide internally valid estimates of the causal effect when analyzing complex program effects and its multiple channels of causality.

Field experiments in the economic development literature often require a parternship with NGOs, financial institutions and governments. Banerjee and Duflo (2009) highligth that advances in field experimentation and their positive results have helped researchers go on undertaking their tasks with financial and other types of support.

\section{Understanding the behavioral foundations of economic development}

The behavioral turn in development economics is a very recent academic phenomenon. Our conjecture is that the researchers' interests in better identifying and diagnosing development problems and policies adjusted their preferences towards experimental data as complement of observational (non experimental) data.

In a paper entitled "New Development Economics and the Challenge to Theory," Banerjee (2005) argues for the idea that the field of development economics needs badly an alternative theoretical framework to explain and predict apparently disparate results arising in the field. Growing robust evidence that some development programs fail also because of individuals' (policy makers as well as their targets) cognitive biases and context dependencies. Examples abound.

Many empirical development studies identify very little fertilizer use in SubSaharan African countries, which turns out to impose severe constraints on small farmers' income and well-being. This issue motivate distinct accounts. Standard explanations draw on the insights from neoclassical economics and go on to that the foregoing phenomenon occurs because of unavailability of fertilizer, its high price or even farmers' asymmetric information. As a result, the policy recommendation involve marketing campaigns to inform people about the gains of fertilizer use and those of fertilizer subsidies. Esther Duflo and her collaborators stress that small farmers in Africa fail to use fertilizers even when they are available to them and the price does not seem to be the most relevant obstable for the increase in farmers returns. In their latest paper on use of fertilizer, they stress that $97 \%$ of farmers they surveyed in Kenya wanted to use fertilizer but only $37 \%$ of them actually did it so (Duflo et al., 2011). Inspired by insights from behavioral economics - hyperbolic discounting (i.e. time conflicting preferences that accommodate present bias and procrastination) and framing effects (context influences) - Duflo and colleagues provide an alternative diagnosis. Farmers do want to fertilize their fields but their intentions cannot be translated by actions because of the different planting and harvest times that give room for self-control problems. Based on their behavioral findings, they run experiments to design very innovative solutions like commitment savings products to help farmers to pursue their goals of fertilizer use. There are many other applications of behavioral designs to nudge people towards better schooling, health and microsavings decisions (Bertrand et al., 2004; Mullanaithan and Shafir, 2013). 
In a nutshell, we partly explain the "behavioral/psychological turn" in terms of advancements in empirical development economics with randomized controlled trials. ${ }^{2}$ However, this is not the whole story at all.

\section{Institutional factors also explain the behavioral turn}

World pressures for institutional changes after the 2008 financial crisis as well as robust evidence of failures in development policies have sensitived important political leaders, NGOs and foundations. Their increasing financial and political support have contributed enormously to the prestige of behaviorally informed development policy and regulation (Barr, Mullanaithan and Shafir 2008; Datta and Mullanaithan 2014). This explains why an increasing number of people from the private and public sectors started to give attention to behavioral economics and make this subfield one of the hottest topics in contemporary regulation and public policy. To our minds, this trend has inspired members of the economics profession to revisit their methodology as well as goals.

It is important to stress that further research on behavioral economic approach to development (and poverty) is required since the phenomena they accommodate are multidimensional and inevitably complex. Our hunch is that a pluralistic perspective on development studies is worth pursuing - institutional factors and historical processes also largely explain poverty and constraints on economic development.

\section{FURTHER EVIDENCE OF THE PAYOFFS OF BEHAVIORALLY INFORMED DEVELOPMENT RESEARCH}

The promise of field experimentation is to dig deeper into psychological processes and mechanisms that explain decision-making under the context of poverty and to provide insights to better guide development programs or policies. This section focuses on some experimental evidence suggesting that insights from behavioral economics are useful to improve diagnosis and policy solutions of some problems like schooling decisions and household finance.

\footnotetext{
${ }^{2}$ We are very grateful to one of our referees, who warned us about an important issue sometimes underestimated by the contemporary literature. There is no compelling grounds for suggesting that the very use of field experiments with randomized controlled trials (RCT) will yield clever interventions or effective development policies. Esther Duflós collaborators worldwide have engaged in some randomized controlled trials that are not free from methodological problems at all (See Cartwright, 2010; Deaton, 2010; Barter and Carter, 2010). Despite the growing use of RCT, field experimentation in economics seems to be a constrained empirical protocol to tackle complex questions, such as causation, causality, generalizability, general equilibrium effects, etc. In response to that, we favor a pluralist perspective that also accommodates sociological and anthropological studies. Together with RCT, such current research developments can help economists pursue a truly explanatory approach to policy test and fine-tuning”.
} 


\section{Schooling decision behaviors in developing countries}

Harvard behavioral economist Sendhil Mullanaithan state that mainstream choice theory explains parents ${ }^{\prime}$ decision over keeping their children at school based on rational cost and benefit analysis. To him, this fails to represent the involved complex choice task that low- income parents face in developing countries. Based on some basic education surveys in India, Mullanaithan detected that parents would like to see their children educated but simply can't find a credible way to stick with that plan (Mullanaithan, 2007, p. 87). This is partly so because poor families have difficulty in dealing with immediate pressures like health circumstances, work problems and liquidity constraints that prevent children from staying in school.

Some behavioural development economists have tested empirically other kinds of incentives to improve school attendance, such as school meals, improved facilities, conditional cash transfers (Banerjee and Duflo 2012). Such experimental settings draw on the conjecture that behavioral insights like loss aversion, status quo bias, default rules and hyperbolic discounting can be useful to come up with designs that "debias" low- income parent's judgments and decisions and allow for improved patterns of choice behavior.

Vermeersch and Kremer (2004) develop an experiment applied in West Kenya to quantify and evaluate the effects of school meals in preschools. Their results suggest that food meals might nudge parents to keep their children at school. They found that school attendance in their treatment group was 30 percent higher both among children previously enrolled and those enrolled because of the program. Improvements in learning also took place in those schools that subsidized children's meals and had experienced teachers.

In another set of studies, Miguel and Kremer (2004) test the effectiveness of a treatment development program for intestinal worms in schools in Kenya on reducing absenteeism. The results suggest that de-worming treatment costs only 49 cents per child per year and reduced absenteeism by one-quarter. The deworming treatment is nearly twenty times more effective to increase school attendance than an alternative program that involved hiring an extra teacher. The abovementioned field experiment sheds some light on the advantages of field experimentation to test and craft better policies. Miguel and Kremer emphasized that other economists, who only focused on observational (non-experimental) data, could not encounter a solution to decrease school absenteeism. The NGO that sponsored the field experiment had considered before an alternative program to increase school attendance, which required to give school uniforms to motivate them to be at school but later proved to be expensive ( $\$ 100,00$ per child per year) and less effective.

In order to evaluate types of education conditional cash transfers in Colombia, Osorio et al., (2011) run an experiment that compares a standard cash transfer design (where low income families receive bi-monthly payments to keep their children at school) with an alternative design that postpone some of the payments until the moment children need to re-enroll in school. Based on previous research 
and surveys suggesting that individuals have time-conflicting preferences and follow default rules, Osorio and colleagues designed a cash transfer that serves the role of a commitment savings strategy. They found out that this transfer design improved re-enrollment especially of those poorest students schools with lowest participation rates across 251 schools.

Similarly, Galiani and McEwan (2011) run a field experiment to test the impact of conditional cash transfer in Honduras. The sample involved participants from the poorest 70 municipalities. Children aged 6-12, who had not completed fourth grade, received the education-based transfers. They found out that the design was a great success - it nudged families towards better options for their children because median school enrollment increased by 12 percent and child labor decreased by 30 percent. For those poorest families, enrollment increased by 16 to 32 percent, while child labor lowered by 50 to 55 percent.

\section{Behavioral field experiments highlight improvements in microfinance}

MFIs have evolved so as to bring new opportunities and choices for some low income individuals overcome poverty and increase their capabilities. Yet behavioral economists suggest that microcredit is not enough to achieve financial empowerment). Microsavings and microinsurance can supplement microcredit in order to enable the poor to make better intertemporal choices related to education, health, investment and consumption (Banerjee and Duflo, 2012; Karlan and Appel, 2012; Duflo and Mitchel, 2014).

In their latest book Poor Economics, Abhijit Banerjee and Esther Duflo claim that poor people - just like everyone else - have to save, even if this comes in small amounts. Savings among the poor is important because they often have to deal with a present and a future. Furthermore, savings enable low-income individuals to build up a financial cushion to cope with eventual risks and disasters. In other words, savings seem to be central for poor's capabilities expansion, financial and social empowerment (2011, p. 184).

Behavioral development experiments promise to design and assess savings products for poor people. Some of the experimental settings draw from evidence of cognitive biases - loss aversion, status quo bias, self-control problems and the human tendency to opt for immediate gains rather than larger future outcomes - to investigate alternative choice designs that help people to commit to their savings plans.

Poor people might demand commitment savings strategies because at least some of them realize the negative consequences of present-biased consumption. For instance, in Africa people often appeal to rotating savings and credit associations named ROSCAs. The latter refers to informal savings devices in which a group of people meets at small intervals and each member contributes a predetermined (small) amount of money. Although ROSCAS pay little or no interest, they remain popular in poor Asian and African countries. They appear to be an effective savings 
scheme to individuals, who are aware of their myopic preferences and anticipate that they cannot save alone (Gugerty, 2001).

Behavioral economics has collected evidence that savings decisions often reveal self-control problems and many people seem to demand commitment devices. Nava Ashraf, Dean Karlan and Wesley Yin run an experiment to test a commitment savings product for the Green Bank of Caraga in the Phillipines (Ashraf et al., 2006). Their aim is to test whether individuals with time-inconsistent preferences would buy a no liquidity savings product that restricts their access to their funds. The product was a new savings product called Save, Earn, Enjoy Deposits (henceforth - SEED) which gave the client the opportunity to commit to save and not withdraw the money invested until a previously agreed goal were achieved: a particular withdrawal date or amount of money. He also had two additional features: he could buy a locked box to make deposits or set up automatic transfers from their bank account into the SEED product. More than $28 \%$ of the clients decided to open this savings account. From those subjects, $83 \%$ opted for the box. The results show also that women and clients revealing hyperbolic time preferences demand strict savings commitment products. After a year, SEED owners saved 80 percent more than the control group and they increased their balances by 337 percentage points on average.

\section{CRITICAL IMPLICATIONS}

Not only does behavioral economics provide insights for improvements in positive economics, but inform normative accounts of welfare and policy-making. Experimental evidence suggesting the causal relevance of framing effect, heuristics and biases and hyperbolic discounting has inspired members of the economics profession to search for new directions in normative economics and to examine the pros and cons of nudging people towards their best interests.

\section{Development policy or programs as nudging and paternalistic interventions}

In his foreword of the book Behavioral Foundations of Public Policy, Kahneman (2013) claims that Richard Thaler and Cass Sunstein's 2008 best-seller book Nudge gave extra boost to the behavioral turn in normative economics and policy. He takes the book as a "manifesto of the behavioral approach to policy." Thaler and Sunstein's book actually inspired many people from the private as well as public sectors. Thaler and Sunstein made bold but convicing statements about the inevitability of choice architecture and the need of nudging people towards better choices.

Behavioral economists' defense of small interventions called nudges draws on the view that actual people are boundedly rational and often make decisions against a particular background or choice architecture - that may prevent them to choose 
what it is in their best interests. The role of nudging is then to change choice architecture in a way that overcomes poor people's cognitive errors and therefore debias their judgment and decision-making. In this sense, nudging is a type of soft paternalistic intervention that preserves freedom of choice.

Some types of nudges are: (i) disclosure of information (for instance, details about the actual credit card rates and consequences of minimum payments) and (ii) warnings and reminders (e.g. information about the benefits and costs of sticking to savings plans, eating healthy, stop smoking). In addition, Sunstein also argues for nudging paternalistic interventions that help individuals to overcome two important bounds of human rationality - limited cognitive capability and willpower.

Bounded cognitive powers refer to the empirical fact that human attention and understanding are scarce resources. In response to that individual judgment and decision-making is very much influenced by context, inertia, default rules and social comparisons. Datta and Mullanaithan (2014) suggests that scarcity of understanding partly explains why many mothers in developing world do not use ORS (oral rehydration solution) that could prevent children from dying of diarrhea.

Bounded willpower refers to self-control problems. As we tried to show in a previous section, hyperbolic discounting improves somehow our understanding of how to design commitment strategies that help the destituted to achieve their longterm preferences.

It is also important to examine critically some objections to nudging as light paternalism, since they are not truly pointless. One source of criticism appeals to the (ethical) values of freedom of choice and autonomy ${ }^{3}$ that some types of nudging undermine (Sugden, 2005; Klick and Mictchel, 2006).

In response to that, Cass Sunstein (2014) claims that nudge interventions resemble a GPS because they steer people's behavior in certain directions but let them free to select an alternative route (if they want to). In this particular case, nudges are not coercive. To him, nudging aims to promote navigability necessary to achieve human welfare improvements. We are not sure if nudges are necessarily conducive to higher freedom of choice only because they are committed to preserving items of individual's choice set. Some designed choice architectures that go beyond reminders and information disclosure (for instance, a national weight loss program) can make use of social pressure, automatic default options or even emotional mechanisms like shame or guilt to influence behavior in certain ways that somehow reduce individuals' autonomy and perceived well-being even when an opt out device is available to them.

A second type of criticism concerns the constraints that nudge paternalism put on individuals' learning potential. This is a troubling issue but there is robust evidence that some development programs about microcredit, mucrosavings and microinsurance helped the poor to learn how to better approximate their financial and entrepreneurial intentions and goals (Armendáriz and Morduch, 2010).

\footnotetext{
${ }^{3}$ Autonomy is defined as the human capacity to reflect and decide how to pursue what they value to achieve.
} 
A third criticism relates to the fact that private and public nudgers are also boundedly rational. Consequently, it is not clear whether they will come up with a choice architecture conducive to what people judge as their best interests (Rizzo and Whitman, 2008). Public or private nudgers may not have the same information and incentives as as those of individuals that are the targets of their regulatory schemes or policies. Furthermore, nudgers are not clearly disinterested parties. Finally, manipulation of choice is an important ethical objection to nudging and choice architecture. Changing automatically default rules, rearranging choice alternatives rather than using subsidies or taxes to influence people's behavior is worrisome to the extent that they reveal a covert or manipulative nature (White, 2013). A manipulative intervention does not fit well with Sunstein's view of nudge as a type of GPS. Interventions that deliberately influences behavior unconsciously or subconsciously are ethically objectionable regardless of their welfare consequences.

\section{CONCLUDING REMARKS}

This paper is an attempt to understand the behavioral (psychological) turn in development economics. Our narrative helps us draw two main lessons. The first lesson is that field experimentation enable empirical development economists to answer new complex questions, such as what mechanisms or processes bring about actual judgment and decision-making among the poor. It opens new windows for problem identification, policy diagnosis, design and testing. Therefore, behavioral development economics brings non-negligible prospects for explanatory progress and predictive improvements. The second lesson is that behavioral economics puts the debate over choice architecture and nudge paternalism in the academic and political agenda. We agree that some types of nudges are perhaps inevitable and even socially desirable. However, it is worth examining critically policy interventions that can undermine individuals' autonomy, learning and agency powers (and rights).

It is important to warn readers about the importance of endorsing a pluralist (methodological and theoretical) perspective on development so as to avoid neglecting causally relevant driving forces of economic prosperity like historical processes and social structures that cannot be controlled by experiments (at least until now).

We end up by suggesting that the behavioral turn will inspire fundamental revisions in the explanations of the micro and macro structures of development and contributes to a fresh view of economics as a behavioral and moral science. This seems to be a promising step towards a richer understanding of some fundamental intersections between facts and values in development economics.

\section{REFERENCES}

Alkire, S.; Deneulin, S. (2009) “The Human Development and Capability Approach”. In: Deneulin, S. and L. Shahani (eds) An Introduction to Human Development and Capability Approach, Earthscan and International Development Research Centre 
Angner, E.; Loewenstein, G. (2012) “Behavioral economics”. In U. Mäki (Ed.), Handbook of the philosophy of science: Philosophy of economics (pp. 641-690). Amsterdam: Elsevier

Armendáriz B.; Morduch, J. (2010) The Economics of Microfinance', Second Edition, MIT Press Books, The MIT Press, edition 2, volume 1, number 0262513986.

Ashraf, N., K.D.; Yin W. (2006) “Tying Odysseus to the Mast: Evidence From a Commitment Savings Product in the Philippines", The Quarterly Journal of Economics 121 (2): 635-672.

Banerjee, A. V., (2005) "New Development Economics and the Challenge to Theory". In: Ravi Kanbur, ed., New Directions in Development Economics: Theory or Empirics? a symposium in Economic and Political Weekly, unpublished paper, August 2005.

Banerjee, A.; Duflo, E. (2012) Poor economics: A Radical Rethinking of the Way to Fight Global Poverty. New York: Public Affairs

Banerjee, A.; Duflo, E. (2009) “The Experimental Approach to Development Economics”. Annual Review of Economics, Vol. 1: 151-178, September 2009.

Banerjee, A.; Duflo, E. (2007) “The Economic Lives of the Poor”, Journal of Economic Perspectives, 21(1):141-167, Winter 2007

Banerjee, A. V., Duflo, E., Glennerster, R.; Kothari, D. (2008, 2010) “Improving immunisation coverage in rural India: clustered randomised controlled evaluation of immunisation campaigns with and without incentives". BMJ : British Medical Journal, 340, c2220

Barrett, C. B and Carter, M.R. (2010). The Power and Pitfalls of Experiments in Development Economics: Some Non-random Reflections. Appl. Econ. Perspect. Pol. (Winter 2010) 32 (4), pp.515548

Bertrand, M., Mullanaithan, S.; Shafir, E. (2004) "Behavioral Economics View of Poverty" The American Economic Review, Vol. 94, No. 2, Papers and Proceedings, (May, 2004), pp. 419-423

Bertrand, M., Mullainathan, S.; Shafir E. (2006) "Behavioral Economics and Marketing in Aid of Decision Making Among the Poor". Journal of Public Policy \& Marketing: Spring 2006, Vol. 25, No. 1, pp. 8-23.

Camerer, C., Loewenstein, G.; Rabin, M. (2003) Advances in Behavioral Economics. Princeton, NJ: Princeton University Press

Camerer, C. \& Loewenstein, G. (2004 [2002]) “Behavioral Economics: Past, Present and Future”. In: Camerer, C.F.; Loewenstein, G. and Rabin, M. (eds) Advances in Behavioral Economics New York, NY: Russel Sage Foundation

Cardenas, J.; Carpenter, J. (2008) "Behavioural Development Economics: Lessons from Field Labs in the Developing World”, Journal of Development Studies, 44:3, 311-338, 2008.

Cartwright, N. (2010). "What Are Randomised Controlled Trials Good For?” Philosophical Studies, 147(1): 59-70.

Conly, S. (2013). Against Autonomy: Justifying Coercive Paternalism, Cambridge University Press, 2013

Datta, S. and Mullanaithan, S. (2014) "Behavioral design: a new approach to development policy". Review of Review of Income and Wealth Series 60, Number 1, March 2014, pp.7-35

Deaton, A.(2010). "Instruments, Randomization, and Learning about Development." Journal of Economic Literature, 48(2), pp. 424-455.

DellaVigna, S. (2009) "Psychology and Economics: evidence from the field', Journal of Economic Literature. 47:2, 315-372

Diamond, P.; Vartiainen, H. (2007) Behavioral Economics and Its Applications. Princeton, NJ: Princeton University Press

Duflo, E. (2006) 'Field Experiments in Development Economics', Working Paper, World Congress of the Econometric Society

Duflo, E. (2010) “A Research Agenda for Development Economics,” AEA Working Paper. Available at http://www.aeaweb.org/econwhitepapers/white_papers/Esther_Duflo.pdf , accessed August 10, 2015

Duflo, E.. (2012) 'Human values and the design of the fight against poverty.' In Tanner Lectures of 
Economics, May 2012, Available http://economics.mit.edu/files/7904., accessed December 10th 2014

Duflo, E., Glennerster R., Kremer M. (2008) 'Using Randomization in Development Economics Research: A Toolkit'. In T. Schultz eJohn Strauss, eds., Handbook of Development Economics. Vol. 4. Amsterdam and New York: North Holland, 2008.

Duflo, E., M. Kremer, J. Robinson (2011) 'Nudging Farmers to Use Fertilizer: Theory and Experimental Evidence from Kenya', American Economic Review, 101, 2350-90, 2011.

Dupas, P.; Robinson, J. (2013) 'Why Don't the Poor Save More? Evidence from Health Savings Experiments', American Economic Review, American Economic Association, vol. 103(4), pages 113871, June 2013.

Dupas, P., S. Green, A. Keats, and J. Robinson (2012) 'Challenges in Banking the Rural Poor: Evidence from Kenya’s Western Province', NBER Working Paper No. 17851

Dworkin, G. (1972) 'Paternalism' The Monist, 56: 64-84

Dworkin, G. (2005) 'Paternalism' The Standford Encyclopedia Of Philosophy (Edited By Edward Zalt).

Friedman, M. (1953) 'The Methodology of Positive Economics.' In Essays on Positive Economics. University of Chicago Press

Frederick, S., Loewenstein, G.; O’Donoghue, T. 'Time Discounting and Time Preference: A Critical Review,' Journal of Economic Literature, American Economic Association, vol. 40(2), pages 351401, June, 2002.

Glaeser, E. (2006) 'Paternalism and Psychology.' University of Chicago Law Review 73 (winter): 133156.

Hands, W.D (2001) Reflection without Rules: Economic Methodology and Contemporary Science Theory Cambridge: Cambridge University Press.

Hands, W.D. (2009) 'The Positive-Normative Dichotomy and Economics,' in Philosophy of Economics, U. Mäki (ed.), Vol. 13 of D. Gabbay, P. Thagard and J. Woods (eds.), Handbook of the Philosophy of Science. Amsterdam: Elsevier, 2012, 219-39.

Heukelom, F. (2013) 'A History of Behavioral Economics.' Cambridge: Cambridge University Press, forthcoming.

Jäntti, M., Kanbur, R.; Pirttila, J. (2014) 'Poverty, Development, and Behavioral economics'. Review of Income and Wealth, Series 60, Number 1, March 2014, pp.1-6

Johnson, E.J.; Goldstein, D.G., (2003) 'Do Defaults Save Lives?’, Science, Vol. 302, pp. 1338-1339, 2003.

Karlan, D.; Appel, J. (2012) More Than Good Intentions: Improving the Ways the World's Poor Borrow, Save, Farm, Learn, and Stay Healthy. New York: Plume

Karlan, D., Ratan, A.; Zinman, J. (2014) 'Savings By and For The Poor: a research review and agenda,' Review of Income and Wealth, Series 60, Number 1, March 2014, pp. 36-78, May (2009)

Laibson, D. (1997) 'Golden Eggs and Hyperbolic Discounting.' Quarterly Journal of Economics, 112(2): 443-477, 1997.

Levitt, S.; List, J. (2009) 'Field experiments in economics: The past, the present, and the future,' European Economic Review, Elsevier, vol. 53(1), pages 1-18, January. 2009.

Loewenstein, G.; Haisley, E. (2008) 'The economist as therapist: Methodological issues raised by 'light' paternalism.' In A. Caplin and A. Schotter (Eds.), 'Foundations of Positive and Normative Economics,' volume 1 in the Handbook of Economic Methodologies, Oxford, England: Oxford University Press.

Madrian, B.; Shea, D. 'The Power Of Suggestion: Inertia In 401(k) Participation And Savings Behavior,' Quarterly Journal of Economics, 2001, v116(4,Nov), 1149-1187

Miguel, E. \& Kremer, M. (2004) 'Worms: Identifying Impacts on Education and Health in the Presence of Treatment Externalities,' Econometrica, Econometric Society, vol. 72(1), pages 159-217, 01.

Mullanaithan, S. (2007) 'Psychology and Development Economics', in Behavioral Economics and Its Applications, edited by Diamond and Vartiainen, Princeton, NJ: Princeton University Press

Mullanaithan, S. and Shafir, E. (2013) Scarcity: Why Having Too Little Means So Much. New York: Times Books 
Narayan, D., Chambers, R.; Shah, M.; P. Petesch (2000). 'Voices of the Poor: Crying Out for Change,'Oxford University Press for the World Bank, New York, 2000.

Prebisch, R. (1949[1982) "El desarrollo económico de la América Latina y algunos de sus principales problemas". In: GURRIERI, A. La obra de Prebisch en la CEPAL. México: Fondo de Cultura Económica.

Robbins, L. (1935) 'An Essay on the Nature and Significance of Economic Science.' 2nd Edition London Macmillan

Sen, A. K. (1982), Choice, Welfare and Measurement. Oxford: Basil Blackwell

Sen, A. K. (1988) 'Freedom of Choice.' European Economic Review. 32. 269-294.

Sen, A. K. (2000) Development as Freedom. Oxford: Oxford University Press.

Shafir, E. (2013) 'The Behavioral Foundations of Public Policy.' Princeton University Press. November 2012.

Rizzo, M. J., \& Whitman, D. G. (2008) ‘The Knowlege Problem of New Paternalism’ NYU Law School, Public Law Research Paper No. 08-12.

Sunstein, C. (2012) 'Behavioral Economics and Paternalism'. Yale Law School, forthcoming

Sunstein, C. (2014) 'The Ethics of Nudging' (November 20, 2014). Available at SSRN: http://ssrn.com/ abstract $=2526341$

Thaler, R.; Sunstein, C. (2003a) 'Paternalism Is Not An Oxymoron', University of Chicago Law Review, vol. 70, Fall, N4.

Thaler, R.; Sunstein, C. (2003b) 'Libertarian Paternalism', American Economic Review, Papers And Proceedings, 93(2): 175-79

Thaler, R.; Sunstein, C. (2009) Nudge: improving decisions about health, wealth and happiness. New York: Penguin Books

Vermeersch, C. \& Kremer, M. (2004) 'School Meals, Educational Achievement, and School Competition: Evidence from a Randomized Evaluation', World Bank Policy Research Working Paper No. 3523.

White, M. (2013) The Manipulation of Choice: Ethics and Libertarian Paternalism. Palgrave Macmillan, 2013

The World Bank (2001) World Development Report 2000/2001: Attacking Poverty. New York: Oxford University Press. (C) World Bank. 